\title{
PARADYGMAT ANTROPOCENTRYCZNY JAKO KATEGORIA LINGWISTYCZNA W BADANIU OBIEKTÓW JĘZYKOWYCH
}

\author{
THE ANTHROPOCENTRIC PARADIGM AS A LINGUISTIC CATEGORY \\ IN LANGUAGE STUDIES
}

ANDRZEJ SITARSKI

\begin{abstract}
This study constitutes an attempt to present views from contemporary cognitive linguistics on the definition and realization of the anthropocentric paradigm in the language system. On the basis of reseachers' opinions, the author comes to the conclusion that a language can be analyzed as a peculiar semantic system whose realization is related to a human being. The available results of linguistic object studies, which take into consideration the anthropocentric paradigm, prove that nowadays anthropocentrism should be presented as a linguistic category.
\end{abstract}

Andrzej Sitarski, Uniwersytet im. Adama Mickiewicza w Poznaniu, Poznań - Polska, sitarski@amu.edu.pl

Ideę antropocentryczności języka we współczesnym językoznawstwie można uznać za powszechnie akceptowalną. Dla wielu językoznawczych metod badawczych pojęcie człowieka $w$ języku występuje $w$ charakterze naturalnego punktu odniesienia $\mathrm{w}$ stosunku do analizowanych zjawisk i obiektów językowych. Zasada antropocentryzmu w językoznawstwie udowadnia, że osiągnięcie adekwatnego pojęcia na temat istoty języka jest możliwe tylko $\mathrm{w}$ wypadku zbadania istoty człowieka uświadamiającego sobie samego siebie, swoje miejsce $\mathrm{w}$ świecie, a także swoją rolę $\mathrm{w}$ działaniach praktycznych. Jednocześnie poznanie człowieka jest niemożliwe bez jego języka. Dlatego tak istotna w badaniach obiektów językowych jest diada "człowiek - język", która powinna znaleźć się w centrum współczesnych badań antropologicznych. E. Seliwanowa w pracy Основы лингвистической теории текста и коммуникации stwierdza, że: „текстово-дискурсивная категория антропоцентричности проявляется в том, что гносеологическим и коммуникативным центром дискурса и текста является человек, его индивидуальное сознание" [Селиванова 2002: 228]. W kategorii antropocentryczności można wyodrębnić podkategorie adresanta i adresata, które funkcjonują w skomplikowanej relacji wzajemnej, charakteryzując się odrębnymi, właściwymi dla siebie środkami realizacji językowej. Pozy- 
cja adresata wkomponowana jest $\mathrm{w}$ tekst, stanowiący przykład znaku językowego zgodnego z założeniem i intencją autora, jego koncepcją adresowanego do odbiorcy tekstu.

Antropocentryczny paradygmat naukowy, który został sformułowany na przełomie XX i XXI wieku, jest twórczo i poznawczo wykorzystywany i rozbudowywany $\mathrm{w}$ opisie obiektów, którymi zajmuje się współczesne językoznawstwo, szczególnie językoznawstwo kognitywne i kulturowe.

Paradygmat antropocentryczny to przeniesienie uwagi badacza $\mathrm{z}$ analizowanego obiektu na podmiot czyli analizę człowieka w języku i języka w człowieku. Człowiek z punktu widzenia paradygmatu antropocentrycznego poznaje rzeczywistość poprzez uświadomienie sobie w niej samego siebie, swojej teoretycznej i empirycznej działalności.

Niniejszy artykuł wpisuje się w nurt badań językoznawczych, które traktują język nie tylko jako środek i narzędzie komunikacji, ale również jako źródło wiedzy o samym człowieku i percypowanej przez niego rzeczywistości. Taka postawa wyznacza antropocentryczny kierunek w badaniach języka, który odwzorowuje świat takim, jakim jest on postrzegany przez człowieka, w jaki człowiek wierzy, a nie taki, jakim ten świat jest w rzeczywistości.

Antropocentryzm jest jednym z najważniejszych paradygmatów stosowanych w metodach badawczych przełomu XX i XXI wieku. Współcześnie paradygmat antropocentryczny jest uwzględniany przez badaczy analizujących zagadnienia kodowania i dekodowania, a także przekazywania informacji za pomocą różnych źródeł, w tym przede wszystkim za pomocą języka. Taka postawa badawcza stworzyła warunki do zbliżenia różnych dziedzin wiedzy, przede wszystkim jednak doprowadziła do humanizacji nauki. Sambor Grucza zauważa, iż

[...] ustawienie konkretnego mówcy-słuchacza, a właściwie jego szeroko pojętych właściwości językowych, w centrum naukowego poznania zaskutkowało intensyfikacją lingwistycznych rozważań [Grucza 2011: 150].

Dostrzegając słuszność założeń teorii antropocentrycznej w badaniach lingwistycznych S. Grucza stwierdza, iż język ludzki nie tylko jest nierozerwalnie związany z człowiekiem, ale ponadto jest on jego kognitywną właściwością konstytutywną [Grucza 2011: 150]. Warto jednak w tym miejscu zaznaczyć, na co zwróciliśmy już uwagę wcześniej, iż współcześnie w lingwistyce funkcjonują równolegle dwa podejścia badawcze do języka: lingwocentryczne (systemowocentryczne) i antropocentryczne, między którymi nie ma żadnej przepaści, chociaż każde $\mathrm{z}$ tych podejść posiada swoje priorytety i swoją dynamikę badawczą. Stymulującym czynnikiem dla językoznawców prowadzących badania w systemie antropcentrycznym jest 
z pewnością aktywnie rozwijające się współcześnie językoznawstwo korpusowe.

Antropocentryzm jako paradygmat współczesnych badań w obszarze lingwistyki pozwala interpretować obiektywną rzeczywistość poprzez pryzmat człowieka. Wszechstronny i głęboki związek człowieka z przyrodą ujawnia się $\mathrm{w}$ kognitywnej jego ewolucji, dlatego też struktura świata poznawana przez homo sapiens nie może nie zostać utrwalona $\mathrm{w}$ jednej $\mathrm{z}$ podstawowych form tego poznania, jaką jest język. Zgodnie z zasadą antropocentryzmu człowiek jest zdolny do opanowania języka $w$ procesie korzystania z niego. Według S. Gruczy ustawienie człowieka i jego rzeczywistych umiejętności językowych w centrum badawczego zainteresowania lingwistyki jest konsekwencją uznania, że punktem wyjścia i ostatecznym punktem odniesienia rozważań lingwistycznych jest konkretny mówca/słuchacz i jego konkretne umiejętności językowe [Grucza 2011: 151].

Język można analizować jako szczególny system semantyczny, którego realizacja pozostaje $\mathrm{w}$ relacji do człowieka, wykorzystującego ten system $\mathrm{w}$ różnych sytuacjach poznawania i interpretowania obiektywnej rzeczywistości. Wpływ rozmaitych czynników, jak stwierdza Krzysztof Korżyk, na konstytuowanie się fenomenu znaczenia, wskazuje jednocześnie na konieczność ujmowania go w perspektywie antropocentrycznej [Korżyk 1992: 64]. J. Apresjan zwraca uwagę, że semantyka znaku językowego odzwierciedla przede wszystkim naiwne pojmowanie rzeczy, właściwości, czynności, procesu, wydarzenia itp. Tworzony przez wieki naiwny obraz świata, w skład którego wchodzą naiwna geometria, naiwna fizyka, naiwna psychologia itd., odzwierciedla materialne i duchowe doświadczenia etnosu posługującego się danym językiem i dlatego może być on dla człowieka jako reprezentanta danego narodu swoisty [Apresjan 1980: 80-81].

Człowiek, percypując świat, tworzy w swym umyśle struktury pojęciowe, które opierają się na doświadczeniu zmysłowym, fizycznym i społecznym oraz na jego działalności. Należy podkreślić, że rzeczywistość nie tworzy w sposób naturalny żadnych klas, modeli czy też kategorii. Dopiero człowiek poprzez swoje doświadczenie klasyfikuje świat, a rezultaty działalności poznawczej człowieka znajdują swoje odzwierciedlenie w języku. Język nie jest jednak wiernym odzwierciedleniem rzeczywistości, lecz odbiciem sposobu patrzenia człowieka na świat. Antropocentryczność języka ujawnia się przede wszystkim $\mathrm{w}$ utrwalanej $\mathrm{w}$ samym języku wiedzy teoretycznej, praktycznej i kulturowej, a także doświadczeniu, które są uświadamiane i werbalizowane przez człowieka poprzez konceptualizację rzeczywistości i jej językowy obraz. Marek Święch zauważa, iż to, jakim jest świat, wydaje się być w dużej mierze zależne od ujęć poznawczych człowieka i języka, którym się on posługuje. M. Święch zwraca uwagę na to, że aktywność życiowa i poznawcza człowieka sprawia, że sam świat staje się 
względny, a nie jego poznanie. Samo poznanie, według M. Święcha, wręcz przeciwnie, pozostaje właśnie jakoś „absolutnie” ważne i obowiązujące $\mathrm{w}$ danym schemacie pojęciowym, w jakim człowiek ten świat ujmuje [Święch 2005: 31]. Warto $\mathrm{w}$ tym miejscu zaznaczyć, że rzeczywistość odbierana przez człowieka, odpowiada na przyjętą przez niego kategoryzację, jaką za pomocą języka człowiek proponuje, czyniąc daną kategoryzację językową prawdziwą lub fałszywą bez względu na akceptację społeczną. Można zadać sobie $w$ tym miejscu pytanie, czy sam język posiada w sobie tyle mocy sprawczej, aby dokonać obiektywnego opisu rzeczywistości. Spojrzenie na język jako system znaków pełniących funkcję interpretacji (kodowania) i transformacji pozwolił Elżbiecie Tabakowskiej stwierdzić, iż postawa antropocentryczna $w$ badaniach języka to

\begin{abstract}
propozycja dla ludzi z wyobraźnią. Dla ludzi, którzy - dostrzegając zalety rygorystycznej formalizacji - mimo wszystko chcieliby wyjść poza sztywne ramy strukturalistycznego obiektywizmu, sięgnąć dalej niż sięga "mędrca szkiełko i oko", którzy w twórcy i użytkowniku języka widzą nie tylko genialny mechanizm do produkowania słów i zdań, ale i kwintesencję jego człowieczeństwa: nieprzewidywalność reakcji, oryginalność spojrzenia na świat, słowem wszystko to, co w połączeniu z uwarunkowaniami kulturowymi i społecznymi decyduje o sposobie, w jaki człowiek używa swojego języka - genialnego narzędzia, którego jest zarówno twórcą, jak i niewolnikiem [Tabakowska 2001: 5].
\end{abstract}

Trudno zaprzeczyć, iż to właśnie człowiekowi, jako podmiotowi poznającemu i władającemu określonym językiem, przypisuje się aktywną rolę $\mathrm{w}$ formułowaniu znaczeń jednostek językowych. Człowiek tworzy znaczenia, a nie otrzymuje je $\mathrm{w}$ gotowej postaci, to on decyduje o wyborze środków językowych dla opisu tej czy innej sytuacji, podejmuje także decyzje dotyczące interpretacji motywów swojego językowego wyboru.

Językoznawcy niejednokrotnie zwracali uwagę na antropocentryczny charakter języka. Wilhelm von Humboldt pojmował język jako czynnik twórczy, będący immanentną cechą umysłu ludzkiego, przy pomocy którego człowiek kształtuje percepcję świata i poglądy na rzeczywistość. Baudouin de Courtenay w pracy Fonologia wyodrębnił antropofonikę jako naukę, której obiektem badawczym są tylko dźwięki artykułowane przez człowieka.

Antropocentryzm języka realizuje się w bardzo różny sposób, lecz tradycyjnie najwięcej przejawów antropocentryzmu odnaleźć można w zasobie leksykalnym. Antropocentryzm jako zasada lingwistycznych badań obiektów językowych jest zorientowany na prowadzenie analizy w dyskursie i tekście materiału empirycznego z uwzględnieniem czynnika ludzkiego $\mathrm{w}$ języku. W dyskursie i tekście jako rezultacie działania językowego wyodrębnić można trzy poziomy realizacji antropocentryzmu: 1. poziom absolutny, który realizuje się poprzez użycie zaimków osobowych oraz form czasownikowych (ja czytam, ty jesteś zapracowany), kategorii nominatyw- 
nych bezpośrednio skierowanych do odbiorcy tekstu w celu kreacji tego lub innego obrazu człowieka (tchórz, inteligentny student); 2. poziom relatywny, określający przy pomocy części mowy fakt przynależności kogoś lub czegoś do człowieka (styl puszkinowski, babcine słowa, nasze sukcesy); 3. poziom pośredni, który sprowadza się do użycia pozostałych środków językowych, odnoszących się do różnych obiektów, ich cech i czynności, które $\mathrm{w}$ jakiś sposób odnoszą się do wyrażenia idei antropocentryzmu, ponieważ wszechświat jest przeniknięty antropocentrycznością (np. słońce, dzień, samochód).

Antropocentryczna perspektywa procesów wyobrażeniowych zachodzących w umyśle człowieka oraz jej zmiany uwarunkowane różnymi typami kategoryzacji językowej (metaforyzacja, metonimizacja) uwzględniającymi mentalność człowieka określają wybór środków i sposobów opisu znaczenia obiektów językowych.

Antropocentryzm przenika wszystkie poziomy organizacji systemu językowego i jego realizację w mowie. Podkreślić jednak należy, na co już zwróciliśmy wcześniej uwagę, iż w leksyce, jako obszarze operacyjnym bezpośredniego współdziałania doświadczenia ludzkiego z obiektywną rzeczywistością, antropocentryzm realizuje się najpowszechniej i najróżnorodniej.

Pardygmat antropocentryczny znalazł zastosowanie również w opisie semantycznym jednostek frazeologicznych i paremiologicznych, co w konsekwencji doprowadziło do rozwoju nowego kierunku w badaniach wymienionych obiektów językowych - frazeologii i paremiologii antropocentrycznej. W sferze paremiologii obserwuje się różny stopień nasycenia przysłów antropocentrycznością. Najwyższy można odnotować w paremiach, w których występują leksemy człowiek, ludzie, np.: człowiek człowiekowi wilkiem, człowiek raz się rodzi i raz umiera, jak my ludziom, tak ludzie nam. Odrębną grupę tworzą przysłowia o średnim poziomie antropocentryczności, których znaczenie odnosi się do zjawisk otaczającego świata, pozostających w relacji do człowieka, np.: szczęśliwy to kraj, który nie ma historii, co kraj to obyczaj, pieniąze sa okragłe, tocza się.

Należy zwrócić uwagę na fakt, iż antropocentryczny aspekt semantyki frazeologizmów uwzględnia te procesy psycholingwistyczne, bez których niemożliwa byłaby językowa działalność komunikacyjna człowieka, a także informacje ukierunkowane na pracę twórczą człowieka, opartą zarówno na jego intuicji, jak i jego świadomej działalności intelektualnej. Czynnik antropocentryczny realizuje się $\mathrm{w}$ przynajmniej trzech sferach tematycznych, które zaproponowane zostały w układzie Wielkiego słownika frazeologicznego Renardy Lebdy. Są to: 1. Natura - człowiek - skłonności, np.: być jak choragiewka na wietrze, cicha woda, być nie w sosie, tchórzem podszyty; 2. Rozwój - człowiek - wartości, np.: bić się z myślami, burza mózgów, coś woła o pomste do nieba, krecia robota; 3. Panowanie nad światem - człowiek 
- ujarzmienie przyrody, np.: coś jest wzięte z kosmosu, gasna czyjeś gwiazdy, [Lebda 2008: 5-6].

Na wyrazisty przejaw antropocentryzmu we frazeologii potocznej zwraca uwagę Anna Pajdzińska, która stwierdza, iż odniesienia do człowieka uwidaczniają się między innymi we frazeologicznych określeniach o znaczeniu temporalnym (smarkata godzina, dziecinna pora), ilości i miary (ktoś ma więcej długów niż włosów na głowie, ile dusza zapragnie, na oko), intensywności cechy (czysty jak łza), przestrzeni (coś komuś uciekło spod nosa) [Pajdzińska 1990: 59-71].

Kontynuacją i uzupełnieniem postawy antropocentrycznej w opisie obiektów językowych dotyczących reprezentacji człowieka w języku, a przede wszystkim w obszarze frazeologii, jest aspekt aksjologiczny, zakładający określenie odpowiedzi na pytanie, jakich wartości oczekuje człowiek w stosunku do samego siebie, otaczających go ludzi i społeczeństwa. Dlatego też z pełnym przekonaniem można stwierdzić, iż aspekt aksjologiczny badań obiektów językowych jest kontynuacją i uzupełnieniem aspektu antropocentrycznego w badaniu języka. Nie wdając się w szczegóły dyskusji naukowej na temat wartości jako kategorii językowej, warto zwrócić uwagę, iż kategoria ta we współczesnym językoznawstwie rozpatrywana jest $\mathrm{w}$ aspekcie pragmatycznym, semiotycznym i teorii aksjologicznej, a obserwowane współcześnie zbliżenie podejścia antropocentrycznego, kognitywnego i pragmatycznego $\mathrm{w}$ badaniu jednostek językowych sprzyja pełniejszemu wniknięciu w obszar badań języka związanych z semantyką wartościującą.

Sumując nasze rozważania na temat antropocentryzmu jako paradygmatu stosowanego w badaniach obiektów językowych, można stwierdzić, iż antropocentryzm realizuje się $\mathrm{w}$ dwóch podstawowych postaciach:

1. Człowiek w języku jawi się jako centrum jakiejkolwiek jego sfery. Przykładem mogą być frazeologizmy, a w komunikacji językowej antropocentryczność realizowana będzie przede wszystkim $\mathrm{w}$ formie egocentryzmu mówiącego, realizowanego poprzez określone akty mowne.

2. Personifikacji świata przedmiotów i zjawisk realizowanych w języku $\mathrm{w}$ postaci animizmów morfologicznych i składniowych, a także antropomorficznej percepcji świata realizowanej $w$ języku poprzez antropomorficzne frazeologizmy, a także personifikację jako środek stylistyczny.

Przestawiona powyżej relacja pomiędzy antropocentryzmem a językiem pozwala na stworzenie przesłanek do systemowej prezentacji antropocentryzmu jako kategorii lingwistycznej. 


\section{Bibliografia}

A p r e s j a n A.D., Semantyka leksykalna, Wrocław-Warszawa-Kraków-Gdańsk 1980.

G r u c z a S., Lingwistyka antropocentryczna a badania okulograficzne, „Linwistyka Stosowana" 2011, t. 4, s. 149-162.

K o r ż y k K., Semantyka kognitywna - problemy i metody (kilka uwag filozoficznych), [w:] Jezyk a kultura, t. 8: Podstawy metodologiczne semantyki wspótczesnej, pod red. I. Nowakowskiej-Kempy, Wrocław 1992.

L e b d a R., Wielki stownik frazeologiczny, Kraków 2008.

P a j d z i ń s k a A., Antropocentryzm frazeologii potocznej, „Etnolingwistyka” 1990, nr 3 , s. 59-71.

С е л и в а н о в а Е.М., Основы лингвистической теории текста и коммуникации, Киів 2002.

Ś w i ę c h M., Antropocentryczna wykładnia realizmu wewnętrznego, "Diametros” 2005, nr 4, s. 29-48.

T a b a k o w s k a E., Kognitywne podstawy języka i językoznawstwa, Kraków 2001. 
